\title{
BETWEEN HUMAN RIGHTS AND NON-PROLIFERATION: NORM COMPETITION IN THE EU'S IRAN POLICY
}

\author{
Benjamin Kienzle ${ }^{1}$ \\ Institut Barcelona d'Estudis Internacionals (IBEI)
}

\begin{abstract}
:
The European Union has been a prominent player in the negotiations with Iran since the beginning of the Iranian nuclear crisis in 2002. However, the Union's Iran policy cannot be reduced to the field of nuclear non-proliferation. Most notably, in the last 20 years it has also promoted human rights and democracy in the country. In other words, the European Iran policy has been a multilayered policy aimed at the diffusion of different kinds of norms. This article examines the consequences of the European Union promoting simultaneously norms from the realms of good governance and international security, in particular regarding the implications for the ever-present characterization of the European Union as a 'normative power'. It focuses especially on the different mechanisms and instruments the Union uses in its norm promotion efforts. In contrast to existing studies on Normative Power Europe, it concludes that in practice the Union faces a dilemma: it can either try to promote coherently all the norms it represents and pay the price in terms of foreign policy effectiveness; or it can try to focus effectively on a single norm and become vulnerable to accusations of double standards.
\end{abstract}

Keywords: European Union, foreign and security policy, norm diffusion, non-proliferation, human rights, Iran.

\section{Resumen:}

La Unión Europea has sido un actor relevante en las negociaciones con Irán desde el principio de la crisis nuclear iraní en el 2002. Sin embargo, la política de la Unión no se puede reducir únicamente al plano de la no proliferación nuclear. Principalmente, en los últimos 20 años ha estado promoviendo derechos humanos y democracia en el país. En otras palabras, la política Europea hacia Irán ha sido una política de múltiples planos cuyo objetivo ha sido la difusión de diferentes tipos de normas. Este artículo examina las consecuencias de la promoción simultánea por parte de la Unión Europea de normas en el campo de la buena gobernanza y en seguridad internacional, en particular en relación con las implicaciones de la clásica caracterización de la Unión Europea como un "poder normativo". Se fija particularmente en los diferentes mecanismos e instrumentos de la Unión para la promoción de sus esfuerzos normativos. En contraste con los estudios existentes sobre la Europa del Poder Normativo, se concluye que en la práctica la Unión se enfrente a un dilema: puede bien intentar promover todas sus normas que representa de una manera coherente y pagar el precio en términos de efectividad de su política exterior; bien tratar de centrarse efectivamente en una única norma y ser objeto de acusaciones de doble estándar.

Palabras clave: Unión Europea, política de seguridad y defensa, difusión de normas, no proliferación, derechos humanos, Irán.

Copyright (C) UNISCI, 2012.

Las opiniones expresadas en estos artículos son propias de sus autores, y no reflejan necesariamente la opinión de UNISCI. The views expressed in these articles are those of the authors, and do not necessarily reflect the views of UNISCI.

\footnotetext{
${ }^{1}$ Dr. Benjamin Kienzle is a Post-doctoral Researcher at the Barcelona Institute for International Studies (IBEI).

E-mail: bkienzle@ibei.org.

http://dx.doi.org/10.5209/rev_UNIS.2012.n30.4070ם
} 


\section{Introduction}

The European Union (EU) has been increasingly recognized as an independent - even though peculiar - actor in international affairs. A widespread way to conceptualize the EU as a new kind of actor has been its characterization as a normative power. ${ }^{2}$ However, even today it is still not clear what the concept of Normative Power Europe really entails. For over ten years, experts have discussed about the different problems and pitfalls of the concept. ${ }^{3}$ Yet, the generally accepted definition has not gone much further than "an identity attributed to a political entity that diffuses its norms in the international system [italics in original]". $\mathrm{A}$ dominant bone of contention in this debate has been the question in how far Normative Power Europe actually means being a 'force for good'. Much of the literature suggests that Normative Power Europe is essentially about the non-coercive diffusion of so-called universal norms such as human rights, democracy and the rule of law, i.e. being a 'force for good'. Increasingly, however, this characterization is put into question. De Zutter argues, for example, that a "normative power is not 'good' because it diffuses norms".

Empirically, the 'force for good' literature has suffered from two shortcomings: First, it has often focused on the diffusion of a single norm or group of norms by the EU. For instance, Manners focused in his original article on Normative Power Europe on the prohibition of the death penalty. ${ }^{6}$ Secondly, country case studies of Normative Power Europe have dealt largely with countries in the EU's neighbourhood, where arguably the EU's influence is larger due to the countries' proximity to the Union. ${ }^{7}$ Consequently, the objective of this article is to shed more light on the 'force for good' interpretation of Normative Power Europe by analyzing a case outside the EU's neighbourhood where the EU has not only promoted universally 'good' norms such as human rights or democracy, but also other norms that do not fit necessarily into this categorization. A useful case in this regard is Iran, where the EU has been a central actor for over 20 years. More specifically, the EU has been a norm promoter both in the case of the Iran human rights and democracy policy and the Iran nonproliferation policy.

The Iran policy of the EU can be traced back to the early 1990s, when it established its 'critical dialogue' with the leadership in Tehran. Ever since, the relations have been dominated by two political issues: the promotion of human rights and democracy and the nonproliferation of nuclear weapons. However, in the wake of the nuclear crisis after 2002 human rights and democracy issues have clearly taken a backseat. For example, the European reactions to the violent suppression of mass demonstrations against the allegedly rigged outcome of the 2009 presidential elections in Iran were at best half-hearted and confused, even though it should have provoked strong and unequivocal protests. After all, the European Union is a self-declared champion of democracy and human rights that applies numerous mechanisms to diffuse its ideas of good governance in the world. How is it possible to explain this apparent lack of action in the context of the concept of Normative Power Europe?

\footnotetext{
2 See Manners, Ian: "Normative Power Europe: A Contradiction in Terms?", Journal of Common Market Studies, vol. 40, no. 2 (2002), pp. 235-258.

${ }^{3}$ For a recent overview, see Forsberg, Tuomas: "Normative Power Europe, Once Again: A Conceptual Analysis of an Ideal Type", Journal of Common Market Studies, vol. 49, no. 6 (2011), pp. 183-204.

${ }^{4}$ De Zutter, Elisabeth: "Normative Power Spotting: An Ontological and Methodological Appraisal", Journal of European Public Policy, vol. 17, no. 8 (2010), p. 1107.

${ }^{5}$ Ibid.

${ }^{6}$ See Manners, op. cit.

${ }^{7}$ See, for example, Barbé, Esther and Johansson-Nogués, Elisabeth: "The EU as a Modest 'Force for Good': The European Neighbourhood Policy”, International Affairs, vol. 84, no. 1 (2008), 81-96.
} 
The most common explanation is to attribute the EU's lack of commitment to human rights and democracy to the EU's negotiations with Iran about the Iranian nuclear programme, which is believed to serve not only civilian but also military purposes. Shortly after the 2009 presidential elections, for example, the European Voice wrote that "The response of the EU to these extraordinary events has been conditioned by its preoccupation with Iran's nuclear programme". ${ }^{8}$ In other words, the argument is that security issues trump human rights considerations. In fact, the dominance of non-proliferation in EU-Iran relations has been highlighted since the beginning of the negotiations between the E3 (France, Germany and Great Britain) and Iran about the Iranian nuclear programme in October 2003. ${ }^{9}$ Although in 2002 the EU began to negotiate with Iran a Trade and Cooperation Agreement (TCA) and a Political Dialogue Agreement (PDA) and initiated the EU-Iran Human Rights Dialogue, within two years the nuclear negotiations got the upper hand. This development has been supported by some pundits, ${ }^{10}$ but many others lamented an overly focus on nonproliferation. ${ }^{11}$ Their underlying critique is that the EU has turned from a 'force for good' that promotes values and principles such as human rights and democracy into a traditional power that acts according to the premises of realpolitik.

This article argues that this critique is overly influenced by the view that the EU is - or rather should be - a normative power in the sense of a 'force for good' that promotes mainly the universally 'good' norms such as human rights or democracy. As has been pointed out already, there are no specific reasons why Normative Power Europe should be linked to the diffusion of certain norms and not to norms in general, which are usually defined as "shared expectations about appropriate behavior held by a community of actors". ${ }^{12}$ Accordingly, the EU can be seen as a norm promoter - or a normative power for that matter - in Iran both in the case of human rights and democracy norms and non-proliferation norms. Yet, none of these norms are by definition superior to the other, as some authors might suggest. For example, during the political dialogue with Iran during the 1990s human rights and democracy issues were more dominant than security related issues such as non-proliferation. The crucial issue is rather that norms - and the mechanisms to promote these norms - are not always compatible. At times, they may even compete with each other, leading to sub-optimal outcomes and undesired side-effects. Arguably, this is what happened in the case of the EU's Iran policy in 2009: the parallel diffusion of competing norms has led to a confusing

\footnotetext{
${ }^{8}$ Vogel, Toby: "Danger and Diplomatic Difficulties", European Voice (9 July 2009).

${ }^{9}$ The EU's relation with Iran in the field of non-proliferation has been already analyzed in-depth. See, for example, Denza, Eileen: "Non-Proliferation of Nuclear Weapons: The European Union and Iran", European Foreign Affairs Review, vol. 10, no. 3 (2005), pp. 289-311; Dryburgh, Lynne: "The EU as a Global Actor? EU Policy Towards Iran", European Security, vol. 17, no. 2-3 (2008), pp. 253-271; Hanau Santini, Ruth: "European Union Discourses and Practices on the Iranian Nuclear Programme", European Security, vol. 19, no. 3, (2010), pp. 467-489; Harnisch, Sebastian: "Minilateral Cooperation and Transatlantic Coalition-Building: The E3/EU-3 Iran Initiative", European Security, vol. 16, no. 1 (2007), pp. 1-27; Kienzle, Benjamin: "The Role of Ideas in EU Responses to International Crises: Comparing the Cases of Iraq and Iran", Cooperation and Conflict (forthcoming); Sauer, Tom: "Coercive Diplomacy by the EU: The Iranian Nuclear Weapons Crisis", Third World Quarterly, vol. 28, no. 3 (2007), pp. 613-633; Sauer, Tom: "Struggling on the World Scene: An overAmbitious EU Versus a Committed Iran”, European Security, vol. 17, no. 2-3 (2008), pp. 273-293.

${ }^{10}$ See Leonard, Mark (2005): Can EU Diplomacy Stop Iran's Nuclear Programme?, Working Paper, London, Centre for European Reform, at http://www.cer.org.uk/publications/645.html.

${ }^{11}$ See Kaussler, Bernd: "European Union Constructive Engagement with Iran (2000-2004): An Exercise in Conditional Human Rights Diplomacy", Iranian Studies, vol. 41, no. 3 (2008), pp. 269-95; Reissner, Johannes (2005): Atomdebatte statt Iranpolitik?, SWP-Aktuell, No. 10, Berlin, Stiftung Wissenschaft und Politik; Youngs, Richard (2006): Europe and the Middle East: In the Shadow of September 11, Boulder, CO, Lynne Rienner.

${ }^{12}$ Finnemore, Martha (1996): National Interests in International Society, Ithaca, NY, Cornell University Press, p. 22.
} 
balancing act between condemning half-heartedly the suppression of the Iranian democracy movements and maintaining the freedom of negotiation in the nuclear sphere.

The specific objective of this article is to analyse in-depth the diffusion of competing norms by the EU and its consequences, especially in terms of the concept of Normative Power Europe as a 'force for good': What happens if the EU tries to promote more than one norm? The article consists basically of two parts: In the first part, I will examine more in detail the role of the EU as a normative power, in particular concerning the norm diffusion mechanisms and instruments. The aim is to establish a conceptual framework for the second part, where I will analyze empirically how the EU diffused in practice its norms in the specific case of the Islamic Republic of Iran: Firstly, I will scrutinize the EU's policies in the field of good governance in a broad sense, including human rights and democracy promotion; secondly, I will examine the EU's non-proliferation policy, especially since 2003. Finally, I will outline in the conclusions what these results reveal about the EU as a normative power in international affairs.

\section{Norms, Norm Diffusion and Normative Power Europe}

In the study of the European Union as an international actor in its own right, norm diffusion and normative power are intimately linked. In a sense, normative power refers to the ability to diffuse norms. Moreover, the concept of Normative Power Europe has become a linchpin of EU foreign policy research. Thus, it is difficult to analyze norm diffusion without taking into consideration normative power. However, the way Ian Manners has conceptualized Normative Power Europe, it is problematic from an analytical point of view, as it makes it difficult to understand how the EU works in international affairs. Three basic, but interlinked issues appear to be particularly important: (a) Which norms does the EU promote? (b) What are mechanisms that the EU uses to diffuse norms? (c) Under which conditions does norm diffusion occur?

The original concept of normative power refers essentially to the "ability to shape conceptions of "normal' in international relations". ${ }^{13}$ Norms, in this sense, have a regulative or prescriptive character as opposed to the constitutive effect they may have in other circumstances. That is, norms are collectively held beliefs in what 'should be'. Although the colloquial use of the word 'norm' might suggest otherwise, there is nothing inherently 'good' or 'bad' about norms: "Norms most of us would consider "bad" - norms about racial superiority, divine right, imperialism - were once powerful because some groups believed in the appropriateness (that is, the "goodness') of the norm, and others either accepted it as obvious or inevitable or had no choice but to accept it". ${ }^{14}$ In other words, norms are only 'good' from the subjective point of view of the norm promoter.

The problem with the Normative Power Europe concept is that what is defined as 'good norms' from the perspective of the European Union is largely limited to the broad field of human rights, democracy and rule of law, whereas other fields - most notably, international security - are often eschewed. Most analyses using Normative Power Europe are actually about the EU policies on human rights, democracy promotion and peacebuilding. More importantly, researchers project on the EU their own believes about what the EU should do in

\footnotetext{
${ }^{13}$ Manners, op. cit., p. 239.

${ }^{14}$ Finnemore, Martha and Sikkink, Kathryn: "International Norm Dynamics and Political Change", International Organization, vol. 52, no. 4 (1998), p. 892.
} 
international affairs. In a sense, Normative Power Europe is a normative concept in itself. Ian Manners is absolutely clear about that: "[Normative Power] was, and is, a statement of what is believed to be good about the EU; a statement which needed to be made in order to stimulate and reflect on what the EU should be (doing) in world politics [emphasis in original]". 15 However, such an approach is prejudicial to the analysis of actual norm diffusion between the EU and other international actors.

But what are these norms in practice? Ian Manners and other authors who focus on human rights, democracy, the rule of law and similar norms highlight only one part of EU norms. Certainly nobody doubts that the EU tries to promote these norms in its external relations. After all, there exists a broad basis for these norms in the Treaties and the acquis communautaire. Yet, other important norms that are not so popular with researcher of Normative Power Europe are left out, even though they are generally accepted in the EU, especially norms in the field of security. Non-proliferation is probably one of the most prominent examples. It is often forgotten that non-proliferation is not an axiom in world politics. It is a rather a widely, though by far not universally held belief that the proliferation of nuclear weapons is something 'bad' that has to be prevented. ${ }^{16}$ At least since the publication of the EU Strategy against Proliferation of Weapons of Mass Destruction in December 2003, the EU has a very clear and strong commitment to non-proliferation in the world. In short, in the European Union there coexist many different norms that - by definition - are considered as something 'good', i.e. as something worth to be promoted. However, there is no guarantee that all these norms are coherent among themselves. ${ }^{17}$ As will be analyzed more in detail in the empirical sections, the promotion of non-proliferation norms may compete with the promotion of human rights norms. Consequently, there exist potential conflicts between different norms that may have important repercussions for the concept of Normative Power Europe.

At the same time the mechanisms to promote or, more in general, diffuse these norms are not necessarily compatible. In some circumstances the promotion of one norm may require a certain type of mechanism, whereas other norms have to be promoted in another way. In practice, there exist numerous mechanisms of norm diffusion. Already in the original work on Normative Power Europe, Ian Manners lists six factors that influence norm diffusion by the EU: contagion, informational diffusion, procedural diffusion, transference, overt diffusion and the cultural filter. ${ }^{18}$ However, norm diffusion processes are even more varied than Manner's six factors suggest. ${ }^{19}$ First of all, it is necessary to distinguish between direct and indirect forms of norm diffusion. In the case of direct norm diffusion, a norm promoter also called a norm entrepreneur - consciously facilitates the adoption of certain norms by others. Indirect norm diffusion, on the contrary, does not require the active promotion of norms. The clearest case in this regard is emulation. That is, an actor emulates norms held by

\footnotetext{
15 Manners, Ian: “The European Union as a Normative Power: A Response to Thomas Diez", Millennium: Journal of International Studies, vol. 35, no. 1 (2006), p. 168.

${ }^{16}$ Exceptions might be North Korea, India, Pakistan and Neorealists such as Kenneth N. Waltz. See Sagan, Scott D., Waltz, Kenneth and Betts, Richard K.: “A Nuclear Iran: Promoting Stability or Courting Disaster?”, Journal of International Affairs, vol. 60, no. 2 (2007), pp. 135-150.

${ }^{17}$ See also Sjursen, Helen: “The EU as a 'Normative' Power: How Can This Be?", Journal of European Public Policy, vol. 13, no. 2, pp. 235-251.

${ }^{18}$ See Manners, "Normative Power Europe...", op. cit., pp. 244-245.

${ }^{19}$ See Börzel, Tanja A. and Risse, Thomas (2009): The Transformative Power of Europe: The European Union and the Diffusion of Ideas, KFG Working Paper Series, No. 1, Berlin, Kolleg-Forschergruppe The Transformative Power of Europe, at

http://www.polsoz.fu-

berlin.de/en/v/transformeurope/publications/working_paper/WP_01_Juni_Boerzel_Risse.pdf.
} 
another actor because they are seen as superior to own norms or simply because it is considered to be appropriate. For example, states outside Europe may imitate the European integration process because the European Union serves as a successful example of regional cooperation or simply because regional integration is seen as the appropriate thing to do. In the context of this article, however, the main focus is on direct forms of norm diffusion, i.e. on the EU as an active norm entrepreneur.

Which mechanisms and instruments does the EU have at its disposal? In contrast to those who believe that norm diffusion is - and should be - only related to non-coercive means, this article accepts that the EU uses in its policies a wide variety of mechanisms and instruments to promote certain norms without arguing that one should be given preference. Even regarding norm diffusion processes the EU is not necessarily a 'force for good'. ${ }^{20}$ Although it has developed unique means to diffuse norms non-intrusively, for example through what Ian Manners calls "informational diffusion" as the result of strategic and declaratory communications, it has also used more coercive instruments of norm diffusion such as sanctions. Functionally, it is typical to distinguish between at least four types of direct norm diffusion, although slight variations exist between different authors. The typology used here depends on how influence is wielded and distinguishes between persuasion, integration, manipulation and coercion. ${ }^{21}$ Persuasion is based on the pure force of the argument. Others basically 'learn from' or become convinced of the superiority of certain ideas or policy positions. Political dialogue, such as the human rights dialogue between the EU and Iran, is the clearest manifestation of this type of norm diffusion. Integration is not substantially different from persuasion, as norm diffusion is still non-coercive. However, the emphasis is not on convincing but on integrating others into a common framework, where the acceptance of certain norms is expected to become a full member. This kind of norm diffusion has been most evident in the EU's enlargement process in the 1990s and, to a lesser extent, in the European neighbourhood policy. Manipulation, the third type of norm diffusion, entails negative or positive incentives to adopt certain norms. Typical examples in this regard are to offer rewards in the form commercial advantages - as will be seen in the offers the EU made to Iran in the nuclear negotiations - or to threaten negative consequences in the form of sanctions. In a sense, norm adoption by a third party is the result of cost calculations. Usually, diplomatic negotiations underpin the manipulation approach. Coercion, finally, is essentially the imposition of norms on others, either by controlling a certain territory or by using military force. In contrast to the other types of norm diffusion, the collaboration of the target entity is not required. Typical examples would be norm diffusion by colonial powers in its colonies or protectorates or the military occupation of another country. As in the case of the norms themselves, norm diffusion mechanisms and instruments are not necessarily compatible. Once more, different means may compete with each other.

In the context of Iran, this competition is largely limited to persuasion and manipulation, as the other two types of norm diffusion - integration and coercion - are virtually impossible to use. Integration is hardly an option, because Iran - as a country outside the EU's periphery - has no perspective of integration with the EU, neither as a member nor as a neighbourhood country. Coercion, for its part, is outside the EU's capabilities. The Union simply lacks the means to impose norms in any way on a country like Iran. Consequently, the analysis of norm diffusion processes between the EU and Iran has to focus on the interplay

\footnotetext{
${ }^{20}$ See also the critique of Merlingen, Michael: "Everything is Dangerous: A Critique of 'Normative Power Europe"', Security Dialogue, vol. 38, no. 4 (2007), pp. 435-453.

${ }^{21}$ The typology is influenced by Wendt's differentiation between force, price and legitimacy as reasons for states to comply with international norms. See Wendt, Alexander (1999): Social Theory of International Politics, Cambridge, Cambridge University Press, pp. 246-312.
} 
between persuasion and manipulation. This interplay may lead to important conflicts in the EU's norm diffusion policies, when the promotion of different norms requires distinct mechanisms and instruments. Such conflicts would require, in turn, the rethinking of the conceptualization of the EU as a normative power.

In sum, the conceptual framework of this article is distinct from classical accounts of Normative Power Europe in two crucial ways: First, it focuses simultaneously on the diffusion of two distinct norms by the EU. Secondly, it takes into consideration all potential norm diffusion mechanisms and instruments instead of focusing on persuasion-only mechanisms as in most traditional accounts of Normative Power Europe. Like this, the article can obtain new insights into the complex reality of the EU as a normative power.

\section{Methodological Considerations}

Methodologically, the article is based on intensive qualitative research focused on a single case study. This kind of research encompasses typically the analysis and systematic interpretation of written and oral records. Qualitative research looks essentially at what is being communicated, either in written form or orally. This includes the examination of how something is communicated and to whom. It also examines the context of communication, i.e. the relation with the material world, for example the correlation between communication and action. The written record that has been analyzed during the research can be sub-divided into two broad categories: (a) official and (b) informal documents. Official documents include a wide range of written material adopted officially by an institution or organism: first, reports or memos; secondly, formal strategic documents, for example the EU Strategy against Proliferation of WMD the European Security Strategy or Commission communications; and thirdly, legal documents, which are usually published in the Official Journal of the European Union. Informal documents, for their part, comprise all type of political statements not adopted officially by an institution or organism. They are usually attributable to a certain politician or official, in particular political proposals, working and policy papers and, above all, speeches.

The analysis and interpretation of the different types of written records has been complemented by interviews, i.e. oral records. The interview type that has been used during the research is mainly the elite interview. According to Buttolph Johnson and Reynolds, "[e]lite interviewing is the process of interviewing respondents in a nonstandardized, individualized manner". ${ }^{22}$ As its name says already, it focuses exclusively on the political elite, i.e. "those with close proximity to power or policymaking". ${ }^{23}$ Usually, face-to-face interviews of varied length (from half an hour to two hours) have been conducted. However, in some instances phone interviews have been the better option, as it has been impossible to travel to all places. In order to structure and guide the interviews better, the semi-structured or focused interview sub-type has been chosen in all cases. In other words, the interviews have been guided by a pre-prepared interview protocol, which includes the major themes and questions to be raised during the interview. Due to the sensitivity of the research topic all interviews have been only on background or non-attributable. In order to obtain balanced and, above all, reliable interview results, interviews have been conducted in the three major EU

\footnotetext{
${ }^{22}$ Buttolph Johnson, Janet and Reynolds, H.T. (2005): Political Science Research Methods, Washington, DC, CQ, p. 271.

${ }^{23}$ Lilleker, Darren G.: "Interviewing the Political Elite: Navigating a Potential Minefield", Politics, vol. 23, no. 3 (2003), p. 207.
} 
institutions (the Council, the Commission and the Parliament) as well as in national diplomatic services of EU Member States. In total, 15 interviews conducted at the end of 2008 and in early 2009 have been used for this article.

The document analyses and research interviews focus on a single case: the EU policies towards Iran. Methodologically, it represents what Lijpart called a "deviant case analysis,",24 as it deviates from "established generalizations" about the EU acting as a normative power in the sense of a 'force for good'. In practical terms, the single case allows unearthing "relevant additional variables that were not considered previously". ${ }^{25}$ In the case of this article, this refers principally to the methods of norm diffusion used by the EU. Theoretically speaking, the added value of this approach is that it "weaken[s] the original proposition, but suggest[s] a modified proposition that may be stronger". ${ }^{26}$ Moreover, by analyzing norm diffusion processes in the case of two different sets of norms, the article strengthens the single case study with two 'within-case analyses'. All in all, the analysis of EU policy towards Iran within a qualitative research framework will not only shed light on one particular EU policy but also on the EU as a normative power more generally.

\section{The European Union, Iran and Norm Diffusion}

In the case of Iran, the EU has been in recent years a norm entrepreneur that promotes, on the one hand, norms of human rights and similar norms such as democracy and the rule of law and, on the other hand, international norms of non-proliferation of nuclear weapons. As has been pointed out already, the two mechanisms at its disposal are essentially the persuasion of Iran and the successful manipulation of Iran's interests. The question is how the promotion of two different norms through two distinct mechanisms has been played out in practice.

\subsection{Human Rights}

The EU's Iran policies in the field of human rights, democracy and the rule of law can be roughly divided into four periods: the critical dialogue period (1992-1997), the early comprehensive dialogue period (1998-2002), the period of multiple dialogues (2002-2004) and the final period without dialogues (2004-present). The EU's so-called critical dialogue with Iran began with a declaration at the 1992 European Council in Edinburgh. ${ }^{27}$ It consisted essentially of meetings between what was then the EU Troika (the current, previous and following Presidency) and its Iranian partners. It was 'critical' insofar as it addressed, at least nominally, the four issues that were crucial for the EU in the case of Iran: human rights, terrorism, regional stability and weapons of mass destruction, even though the first issue dominated from the very beginning. To a certain extent it was a remarkable first attempt at implementing the Common Foreign and Security Policy (CFSP), especially because it contradicted US policies of complete isolation of the regime in Tehran. ${ }^{28}$ In practice, however, the critical dialogue failed to change the behaviour of Iran in any significant way, not least regarding human rights. Not surprisingly, the Troika meetings were criticized as

\footnotetext{
${ }^{24}$ Lijphart, Arend: "Comparative Politics and the Comparative Method”, American Political Science Review, vol. 65 , no. 3 (1971), p. 692.

${ }^{25}$ Ibid.

${ }^{26}$ Ibid.

${ }^{27}$ For an overview see Reissner, op. cit.

${ }^{28}$ In 1996, the United States adopted the controversial Iran and Libya Sanctions Act, which even targeted European companies doing business in Iran.
} 
"empty rituals". ${ }^{29}$ Most notably, the critical dialogue was not accompanied by economic incentives or threats of sanctions in case certain benchmarks would not have been accomplished. The EU was probably still not mature enough to contemplate stronger alternatives to this pure persuasion approach. The important point, however, is that the critical dialogue established a logic of persuasion as the dominant element in the EU's dealings with Iran in the field of human rights, democracy and the rule of law. It became, thus, a normative power in the classical sense of a universal norm promoter that uses exclusively persuasionbased mechanisms. Although the suspension of the critical dialogue and withdrawal of European ambassadors in the wake of the 1997 verdict in the so-called Mykonos trial in Germany was a clear resort to manipulation mechanisms in the form of political sanctions, the persuasion logic remained dominant even after the Mykonos trial. ${ }^{30}$

In 1997, shortly after the Mykonos verdict, the election of the reformer Mohammad Khatami as president of Iran opened up a new "window of opportunity" for a renewal of EUIranian dialogue. ${ }^{31}$ Thus, in 1998 the EU initiated the so-called comprehensive dialogue. To a large extent this dialogue was old wine in new bottles: It consisted of EU Troika meetings with Iranian officials at the level of deputy ministers twice a year. It also addressed once more the four key issues of human rights, terrorism, regional stability and weapons of mass destruction, though it were once more human rights topics that were clearly at the forefront. Most of the time the EU was supportive of the new government of Mahommad Kathami. Even though it issued a few critical CFSP statements on the treatment of Iranian Jews, intellectuals and students, ${ }^{32}$ it refrained from any kind of punitive actions and continued to pursue a persuasion-based approach. Although the EU's use of persuasion is often portrayed as a new way of making foreign policy - especially in contrast to traditional power politics it should be pointed out that the persuasion element in the EU's comprehensive dialogue with Iran had also a clear commercial rationale. In short, the EU did not want to alienate its Iranian partners with a confrontational human rights policy based on the logic of manipulation. It was eager to promote its commercial interests, particularly regarding oil and gas, as well as its strategic presence in a major country, where the United States chose not get involved in. It comes, therefore, as no surprise that after 1998 the EU established Working Groups with Iran on energy and trade and investment as well as ad hoc expert meetings on drugs. ${ }^{33}$

A major watershed in EU-Iranian relations came in 2002. Although the comprehensive dialogue continued beyond this date, it was now flanked by two other processes: The negotiation of a TCA and PDA ${ }^{34}$ and the establishment of a specific human rights dialogue. ${ }^{35}$ Since the re-election of Mahommad Kathami as president of Iran in 2001, the EU has been eager to intensify its relations with Iran in order to strengthen the reformists in the political system in Iran. The initiation of negotiations of a TCA in combination with a PDA at the end of 2002 was certainly a significant step forward. It was also an important incentive for agreeing on a more forceful human rights dialogue as part of a wider EU policy of human

\footnotetext{
${ }^{29}$ Ibid., p. 34.

${ }^{30}$ The Mykonos trial implicated directly Iranian government officials in the killing of Kurdish-Iranian opposition leaders in the Mykonos restaurant in Berlin.

${ }^{31}$ Youngs, op. cit., p. 68.

${ }^{32}$ Many CFSP statements during this time were actually sympathetic to Iran and endorsed, for example, the election and re-election of Mahommad Kathami in 1997 and 2001.

${ }^{33}$ See Martínez Carbonell, Belén: "EU Policy Towards Iran”, in Reissner, Johannes and Whitlock, Eugene (eds.) (2004): Iran and Its Neighbours: Diverging Views on a Strategic Region, vol. 2, Berlin, German Institute for International and Security Affairs, pp. 17-23.

${ }^{34}$ Ibid.

${ }^{35}$ See Kaussler, op. cit.
} 
rights policies with third countries. ${ }^{36}$ This human rights dialogue was once more based on the persuasion logic, though the persuasion mechanism was significantly improved: It consisted of EU-Iran meetings on different human rights topics twice a year and included, except in the meetings restricted to government officials, members of civil society in Europe and Iran. Moreover, the issues that could be addressed were not limited, i.e. the EU could bring up even topics that were irritating for its Iranian counterparts. Most importantly, however, progress of the human rights dialogue was monitored according to previously agreed benchmarks such as Iranian adhesion to international human rights agreements or improvements in certain areas. In sum, by 2003 the EU talked with Iran about human rights in three forums: in the framework of the comprehensive dialogue, in the human rights dialogue and as part of the TCA negotiations, which includes chapters on good governance, in general, and the inclusion of a human rights clause. In other words, the EU became a major promoter of human right norms in Iran, at least until 2004/2005, when all three strands of dialogue were frozen. The promotion of other norms, most notably non-proliferation norms, did only play - if at all - a subordinate role.

In terms of the diffusion of human rights norms, the period between 2002 and 2004 was at least initially successful, when Iran agreed to small steps towards the improved respect for human right standards, e.g. by collaborating with a UN rapporteur on human rights. ${ }^{37}$ In the Council Conclusions evaluating for the first time the human rights dialogue, the EU welcomed explicitly the Iranian progress in terms of human rights, even though it remained critical. ${ }^{38}$ It appeared that the EU's persuasion based approach reaped its first fruits, since, apart from the incentives provided indirectly by the TCA negotiations, manipulation approaches in form of clearer incentives or sanctions were largely absent. For example, until 2005 the EU did not issue a single CFSP statement that might have put pressure on the Iranian government in the field of human rights and democracy.

However, in 2004 things began to change slowly. The 2004 Council Conclusions on the progress of the human rights dialogue with Iran were particularly outspoken in its criticism of Iranian human rights policies and lamented the lack of progress by Iran: "The evaluation clearly establishes that with regard to the issues that this Council has designated as its priorities, although there seemed to be hopeful signs at some point, little overall progress has been achieved since the start of the dialogue in December 2002". ${ }^{39}$ Not surprisingly, at the end of 2004 EU Member States began to sponsor again a critical human rights resolution on Iran in the UN General Assembly - something they continued to do during the following years. From 2005 on, when the EU issued its first critical CFSP statement on Iran since 2001, the number of CFSP statements condemning human rights violations in Iran have risen dramatically. In 2008, the number of CFSP statements on human rights in Iran peaked at 17. Part of the explanation is certainly the recovery of conservatives in the political system in Iran: In February 2004 conservative forces won the parliamentary elections in Iran and, crucially, Mahmoud Ahmadinejad, a conservative hardliner, won surprisingly the 2005 presidential elections. The conservative revival made human rights cooperation with Iran increasingly difficult. In December 2003 the last meeting in the framework of the Comprehensive dialogue was held, while in June 2004 Iran participated for the last time in the

\footnotetext{
${ }^{36}$ See Youngs, op. cit., p. 73.

${ }^{37}$ See Kaussler, op. cit. and Youngs, op. cit.

${ }^{38}$ General Affairs and External Relations Council (2003): 2495th Council Meeting: External Relations, 6941/03 (Presse 63), Brussels (18 March 2003), pp. 11-12.

${ }^{39}$ General Affairs and External Relations Council (2004): 2609th Council Meeting: External Relations, 12770/04 (Presse 276), Luxembourg, 11 October 2004, p. 11.
} 
human rights dialogue. Ever since, Iran has refused to accept the EU's conditions for continuing both the comprehensive and human rights dialogues.

More interestingly, however, the EU's reaction to these Iranian challenges of its persuasion based approach is that it did not resort to a more forceful manipulation approach, using in particular economic incentives and sanctions to promote human right norms in Iran. Although the number of CFSP statements on Iranian human rights violations has increased substantially, the EU refrained from more dramatic measures. This has become particularly clear in its half-hearted reaction to the allegedly rigged outcome of the 2009 Iranian presidential elections, which led to massive protests in the streets of Tehran. Even in the face of the arrest of Iranian personnel working for embassies of EU Member States, the EU's response was at best cautious: EU statements and Council Conclusions certainly condemned the violence against protesters and the arrest of Iranian citizens working for EU embassies, but it did not go further. In this regard, two points should be highlighted: First, despite critical statements by leaders of several EU Member States, the results of the presidential elections, i.e. the victory of Mahmoud Ahmadinejad, was not openly questioned. Secondly, even modest forms of protest that have been used frequently by the EU, e.g. the coordinated withdrawal of all EU ambassadors, have not been carried out. Although such measures have been contemplated, they have not found the necessary support among EU Member States. In short, the active promotion of human rights norms by the EU in Iran has taken a backseat. The main reason is that the diffusion of human rights norms competed at that time with the promotion of another kind of international norm, namely, the non-proliferation of nuclear weapons. Yet, such a norm competition perspective is novel for most traditional analyses of Normative Power Europe. It is, therefore, crucial to analyze how this competition turned out in practice.

\subsection{Non-Proliferation of Nuclear Weapons}

Originally, the EU pursued a persuasion based approach regarding the non-proliferation of Weapons of Mass Destruction in Iran. In the framework of both the critical and the comprehensive dialogue the EU talked with Iran about non-proliferation issues, though human rights topics were much more dominant. This changed radically in 2002 and 2003 when the EU learnt for the first time of actual clandestine nuclear activities of Iran: In August 2002, information about an Iranian nuclear programme were leaked to the Western press and in March 2003 the International Atomic Energy Agency (IAEA) confirmed the existence of undeclared nuclear activity in Iran. As the US administration at the time was bogged down in Iraq and refused to get involved in Iran, it was the EU that took gradually the lead in the nuclear issue in Iran. The discovery of the clandestine nuclear programme in Iran made European leaders believe that the previous persuasion based approach was a failure: Iran did not comply with even basic non-proliferation norms, i.e. transparency and close cooperation with the IAEA. Therefore, the dialogue policy was substituted with a manipulation approach that has manifested itself in three aspects: first, in the use of negotiations instead of dialogue; secondly, in the use of commercial and economic incentives; and thirdly, in the use of sanctions. Thus, the EU switched in its norm promotion approach to Iran from persuasion to manipulation.

The nuclear negotiations with Iran began in October 2003, when the three foreign ministers of France, Germany and Great Britain - the so-called E3 - travelled to Tehran to negotiate directly with the Iranian leadership about ways to solve the nuclear issue. Already their first trip led to a tangible success for the new negotiation approach: Iran signed the socalled Tehran Agreement, which foresaw the suspension of the controversial nuclear activity (the establishment of a uranium enrichment programme) and the adherence to the so-called 
Additional Protocol of the IAEA, which entails a particularly strong inspection mechanism. Although the E3 format was originally not an EU formation in the strict sense, the E3 embedded their approach firmly in the context of EU policies regarding Iran and counted with the consent of the other EU members in the Council. In December 2003, Javier Solana, then the High Representative for the CFSP, joined formally the E3 negotiation team, thus integrating the E3 firmly within the EU as the so-called EU/E3. In 2004, the negotiations with Iran continued, as the practical implementation of the Tehran Agreement led to disagreements between the EU/E3 and Iran. They culminated in November 2004 in the Paris Agreement, which renewed the Iranian pledge to suspend its controversial uranium enrichment project. It also established three working groups for further negotiations on nuclear technology, commercial issues and security matters. With the election of Mahmoud Ahmadinejad, however, the negotiations became increasingly confrontational. Most notably, shortly after the 2005 presidential elections, Iran resumed its uranium enrichment project and began to convert uranium (a preliminary stage of uranium enrichment). Consequently, the EU/E3 broke off its broad negotiations with Iran. It was able, however, to negotiate concerted actions with the three non-European UN Security Council members (China, Russia and the United States), first in the framework of IAEA Board of Governors and later directly in the Security Council. Like this, the EU/E3 became what is known within the EU institutions as EU/E3+3. ${ }^{40}$ Javier Solana, who was already the chief negotiator of the EU/E3, became also the lead negotiator for the EU/E3+3. Since 2005, he and his successor, Catherine Ashton, have held numerous rounds of negotiations with their Iranian counterparts.

During these negotiations, the EU/E3 and later the EU/E3+3 have used both incentives and sanctions to entice Iran to sign a new agreement that would prohibit clearly the development of an own Iranian enrichment programme. ${ }^{41}$ At a more abstract level, incentives and sanctions have been used to promote the acceptance by Iran of what the EU/E3+3 considered to be essential non-proliferation norms such as transparency. The incentives took mainly the form of framework agreements that were offered to Iran, first by the EU/E3 in 2005 and later by the EU/E3+3 in 2006 and 2008. Key provisions in these agreements include in more or less direct terms security assurances, in particular by the EU's nuclear weapon states (France and Great Britain); active support for a civilian nuclear programme in Iran; stronger commercial ties, including in the field of the energy and aviation sector (to renew Iran's ageing fleet of commercial planes); the completion of the TCA negotiations with the EU; or support for Iran's accession to the World Trade Organization. Even the imposition of sanctions were accompanied by incentives: first, in the form of the 'suspension-forsuspension formula,' i.e. the suspension of sanctions in return for the suspension of enrichment activities in Iran; later as part of the 'freeze-for-freeze' offer that foresees no new sanctions in return for no new nuclear activity in Iran. However, all these incentives have not been sufficient to bring about more tangible results.

The same can be said for the sanctions - in a broad sense - that have been imposed on Iran since 2003. These sanctions took basically three forms: First, the suspension of TCA/PDA negotiations was used already early on as a penalty for Iran's nuclear activity: first, in June 2003, later in August 2005, i.e. after the negotiations had been resumed again in January the same year. When it became clear that this kind of sanction did not have the desired effect, the EU/E3+3 began to work on sanctions imposed by the UN Security Council. So far, four rounds of sanctions have been carried out (based on Resolutions 1737/2006, 1747/2007, 1803/2008 and 1929/2010). The sanctions are targeted directly at the nuclear

\footnotetext{
${ }^{40}$ The EU/E3+3 are also known as P5+1, i.e. the five permanent members of the Security Council plus Germany.

${ }^{41}$ Such a programme would allow Iran to develop potentially nuclear weapons.
} 
programme and include measures such as the prohibition of the import or export of nuclear related equipment and technology, the freezing of bank accounts of people involved in the nuclear programme or travel bans. Finally, in 2012 the EU has also resorted to unilateral sanctions, most notably an oil embargo. These sanctions are so strict that it was impossible to find consensus for them in the Security Council.

Concerning the EU's human rights policy in Iran, the most visible outcome of this manipulation based approach has been the increasing competition with the nuclear issue in EU-Iran relations. Ultimately, it has been very difficult to integrate human rights in the manipulation based approach to the nuclear issue: First, Iran has learnt very well to play off the nuclear card against the human rights card. In the wake of the controversy surrounding the 2009 presidential elections, for example, the Financial Times quoted the Iranian military chief of staff as saying that "...the alleged 'interference of this [EU] in the post-election riots' means the bloc had "lost its qualification to hold nuclear talks". 42 Furthermore, the Iranians have portrayed the EU's human rights policy as a pretext for regime change as advocated by the United States. Secondly, in order to achieve concrete results in its nuclear negotiations with Iran the EU needs a strong interlocutor that is able to deliver. Consequently, weakening the regime in Tehran with a more forceful human rights policy with clear manipulation elements is counterproductive. Once more, this has been very obvious in the aftermath of the 2009 presidential elections, when the EU as a whole refrained from questioning openly the election results and, thus, the legitimacy of the incumbent, Mahmoud Ahmadinejad. Although initially some EU leaders were particularly outspoken in their criticism of the election results, all accepted ultimately the de facto outcome of the elections. Thirdly, the use of sanctions in manipulation based approaches leave little room for focusing on two issues at the same time, as the need to impose sanctions does not coincide always. For instance, Iran's refusal to participate in the human rights dialogue after 2004 could have led to specific sanctions. However, at the same time, the EU was negotiating with Iran about its nuclear programme, which did not allow - at the time - the imposition of human rights sanctions. This shows how difficult it is to maintain an approach based on manipulation, i.e. negotiations with incentives and sanctions, if it does not focus on a single issue. Although the EU has never given up its integrated approach to the four key issues already outlined in the first half of the 1990s, i.e. human rights, regional stability, terrorism and weapons of mass destruction, since 2003 nonproliferation has increasingly substituted human rights as the EU's primary issue. The crucial Council and European Council Conclusions on Iran have dealt more and more with the problem of the Iranian nuclear programme. In interviews for this article, several European civil servants and diplomats also admitted - though reluctantly - that the nuclear issue has become indeed the EU's main preoccupation. In short, the EU as a normative power has prioritized the promotion of one norm over other.

The question that remains is why the EU switched from a persuasion- to a manipulation based approach in the case of non-proliferation, but not in the case of human rights. After all, there are no clear indications that the EU values more non-proliferation norms than human rights norms. The first explanation is rather trivial: It was a matter of timing. Whereas in 2003 the human rights dialogue still appeared to be working, the discovery of a clandestine nuclear programme showed that the previous persuasion-based approach to non-proliferation had failed. Therefore, the EU used a manipulation based approach first in the area of nonproliferation. As such an approach requires the focus on a single issue - as has been pointed out above - the EU could not turn to manipulation mechanisms at a later stage in the field of human rights. Secondly, in case of doubt the EU appears to give preference to security norms

\footnotetext{
${ }^{42}$ Blitz, James: “'Interference' Rules EU out of Iran Talks”, Financial Times, 2 July 2009.
} 
over human rights or other norms in the broad field of good governance. This can be seen, for instance, in the 2003 European Security Strategy, where security is given priority over development issues: "Security is a precondition of development". ${ }^{43}$ Thirdly, in the wake of the 2002/2003 nuclear crisis with Iran, the Council and the big Member States took over the EU's Iran policy that had been dominated until then by the European Commission. With the growing marginalization of the Commission, human rights in the EU's Iran policy issues lost increasingly an important advocate. This development was aggravated with the end of the comprehensive and human right dialogues as well as with the suspension of the TCA negotiations, where the Commission participated in the first line. Until the establishment of the European External Action Service, the Commission's DG RELEX had only one desk officer working on Iran. Not surprisingly, the Commission's activities in Iran have been very limited, for example through the inclusion of Iran in Erasmus Mundus, an international academic exchange programme.

\section{Conclusions}

In the last two decades, EU policies on Iran have had two dominant topics: the nonproliferation of nuclear weapons and human rights. More specifically, the EU has tried to promote both international non-proliferation and human rights norms in Iran. In a sense, the EU has been a normative power that has tried to diffuse these two norms in Iran. However, since 2002/2003 the diffusion of two different, though not necessarily exclusionary kinds of norms has led to a growing norm competition. Although both human rights and nonproliferation norms are key elements of European foreign policy as exemplified by the Treaties and the European Security Strategy, in practice they have been difficult to reconcile. A key issue in this regard have been the mechanisms to diffuse norms. In countries like Iran the EU has essentially two mechanisms at its disposal: persuasion, especially in the form of dialogues, and manipulation through a mix of negotiations, incentives and sanctions. Originally, the EU pursued persuasion based approaches regarding both human rights and non-proliferation norms. Between 2002 and 2004, however, the persuasion approach largely failed. Consequently, the EU turned to the manipulation mechanism in order to bolster its norm diffusion policies. However, it turned out that manipulation mechanisms work only regarding single issues. In other words, human right norms competed with non-proliferation norms in the EU's application of manipulation mechanisms, in particular incentives and sanctions. Although non-proliferation prevailed early on over human rights, there has been a continuous tension in the EU Iran policy between the promotion of human rights and nonproliferation norms. This tension has come to the fore in particular in the wake of the 2009 presidential elections, when the EU condemned reluctantly the violent protests against the allegedly rigged outcomes of the elections while trying to maintain a viable negotiation option about nuclear issues with the regime in Tehran. Only the successful conclusion of the current rounds of nuclear negotiations between the EU/E3+3 and Iran would allow refocusing the EU's efforts on the promotion of human rights and democracy.

What does this mean for the EU as an international actor and, more specifically, for the EU as a normative power? So far, most analyses of Normative Power Europe have only looked at cases of the diffusion of single norms in neighbouring country. However, by focusing on the diffusion of two competing norms in a non-neighbourhood country it has been

\footnotetext{
${ }^{43}$ European Council (2003): European Security Strategy: A Secure Europe in a Better World, Brussels, 12 December 2003, p. 2.
} 
possible to flesh out the Normative Power Europe concept with new insights and to broaden its applicability in practice. First of all, Normative Power Europe is a much more complex and multilayer concept than it appears to be in the 'EU as a force for good' literature. It is certainly not shorthand for a new, postmodern way of making foreign policy. As the case of Iran shows, the EU has to deal at times with norm issues that compete with each other, even though they are all perfectly legitimate. Sometimes it is simply not possible to address different norm issues at the same time, especially when the application of the necessary mechanisms are not compatible. This can easily lead to confusion about what norms the EU actually promotes, both within the EU and the targeted third country. As a consequence, the EU's power to act normatively in its foreign policy can diminish significantly, especially outside its immediate neighbourhood where it does not have its special force of attraction. The EU faces, therefore, an important dilemma in its international norm promotion efforts: On the one hand, it can focus on a single issue, e.g. non-proliferation, human rights or even economic governance, and implement forceful policies regarding this issue. This is particularly true if the EU is confronted with concrete challenges such as rigged presidential elections or a clandestine nuclear programme. The problem is, however, that it has to prioritise norms that may appear to be equally important, e.g. non-proliferation and human rights. Therefore, it can be easily accused of double standards, especially if it prioritises certain norms in one country but not another. On the other hand, the EU can try to promote all norms it considers important without prioritising them and, thus, pursue at least a normatively coherent foreign policy. Yet, such a strategy may be difficult to adapt to concrete cases, where the EU has to respond flexibly to concrete challenges to norms such as nuclear weapons projects or human rights violations. In short, as a normative power, the EU faces an important dilemma between normative effectiveness and normative coherence that is not easily to solve in practice. 